\title{
AKTIVITAS ANTIFUNGI EKSTRAK DAUN PEPAYA TERHADAP Candida Albicans PADA BASIS GIGI TIRUAN LEPASAN
}

\author{
Sintha Nugrahini, Dewi Farida Nurlitasari \\ Bagian Prostodonsia, Fakultas Kedokteran Gigi Universitas Mahasaraswati Denpasar \\ email: sintha_pramudhita@yahoo.com
}

\begin{abstract}
Plaque accumulation on removable denture may induce Denture Stomatitis (DS). Candida albicans is the main microorganism that causes DS. To prevent DS, dentures need to be cleaned. The simplest denture cleaning method is immersion using chemicals. Papaya leaf (Carica papaya) contain antifungi substance, could be used as denture cleanser. The aim of this study was to prove the effectivity of papaya leaf extract to decreasing the number of Candida albicans colonies on acrylic resin plates and thermoplastic nylon. This study was pretest-posttest with control group design, 32 samples (16 acrylic resin plates, 16 thermoplastic nylon plates) were divided into 4 groups: immersion using aquadest, fittydent ${ }^{\circledR}$, papaya leaf extract 10\% and 40\%. Paired T-test showed the means of Candida albicans number on acrylic resin plates after immersion of aquadest, fittydent $^{\circledR}$, papaya leaf extract $10 \%$ and $40 \%$ were $0.75 \pm 2.98 \mathrm{CFU} / \mathrm{ml}, 82.5 \pm 1.29,53.5 \pm 3.31 \mathrm{CFU} / \mathrm{ml}, 81.5 \pm 2.38$ $\mathrm{CFU} / \mathrm{ml}$. The means of Candida albicans number on thermoplastic nylon after immersion of aquadest, fittydent ${ }^{\circledR}$, papaya leaf extract $10 \%$ and $40 \%$ were $0.5 \pm 1.73 \mathrm{CFU} / \mathrm{ml}, 82.25 \pm 2.21 \mathrm{CFU} / \mathrm{ml}, 70.25 \pm 3.3 \mathrm{CFU} / \mathrm{ml}, 80.50 \pm 3.69 \mathrm{CFU} / \mathrm{ml}$. Oneway ANOVA test showed no significant differences number of Candida albicans colonies ( $p>0.05$ ) after immersion using fittydent ${ }^{\circledR}$ and papaya leaf extract $40 \%$ on both plates (100\% Candida albicans cells died after immersion). The decrease percentage shown in the immersion of papaya leaf extract $10 \%$ group $(66.67 \%$ on acrylic resin plates and $87.8 \%$ on thermoplastic nylon). This study concluded that papaya leaf extract was effective in decreasing the number of Candida albicans colonies on acrylic resin plates and thermoplastic nylon.
\end{abstract}

Keywords: Papaya leaf extract, Candida albicans, acrylic resin plate, nylon thermoplastic.

\section{PENDAHULUAN}

Perlekatan mikroorganisme pada permukaan gigi tiruan akan berproliferasi membentuk plak gigi tiruan yang mempengaruhi keadaan rongga mulut dan kesehatan sistemik, perlekatan mikroorganisme menyebabkan bau mulut dan denture stomatitis. Pemakai gigi tiruan perlu memperhatikan kebersihan gigi tiruan untuk meningkatkan kesehatan rongga mulut. Pembersihan gigi tiruan dapat dilakukan dengan cara mekanik, kimia, atau kombinasi mekanik dengan kimia. Pembersih kimia lebih efektif untuk menghilangkan biofilm, stain, dan kalkulus. ${ }^{1}$

Basis gigi tiruan dapat didefinisikan sebagai bagian dari gigi tiruan yang bertumpu pada jaringan lunak dan tidak termasuk gigi artifisial. ${ }^{2}$ Basis gigi tiruan mendukung gigi artifisial, menerima kekuatan fungsional pada saat oklusi dan mentransfer kekuatan fungsional untuk mendukung struktur oral secara berkelanjutan. ${ }^{3}$ Bahan-bahan basis gigi tiruan yang sering digunakan adalah resin akrilik, nilon termoplastik. ${ }^{4}$

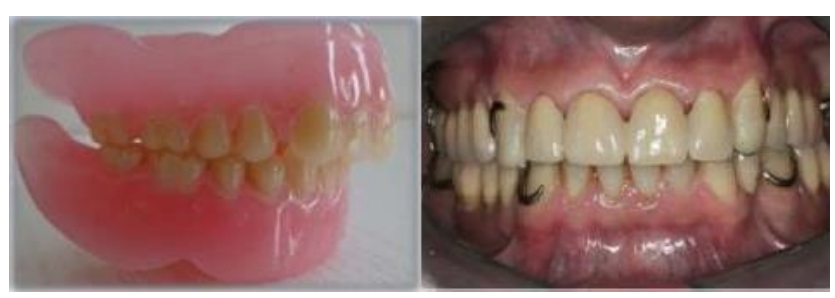

Gambar 2.1. Gambar gigi tiruan lepasan berbahan resin akrilik polimerisasi panas. ${ }^{4}$

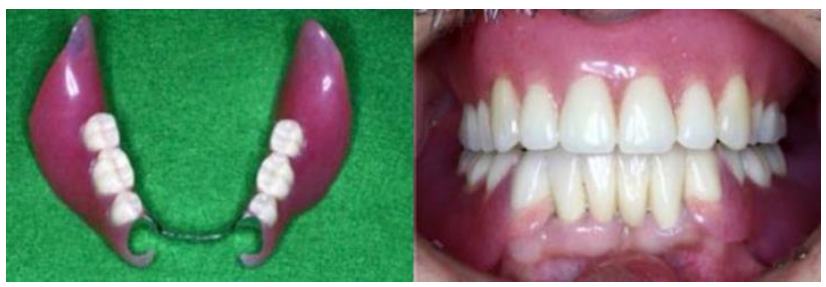

Gambar 2.2. Gambar gigi tiruan lepasan berbahan nilon termoplastik. ${ }^{4}$

Plak pada gigi tiruan merupakan faktor penting yang dapat menyebabkan inflmasi pada mukosa palatal dan terjadinya denture stomatitiss. ${ }^{5}$ Denture stomatitis adalah suatu inflamasi pada mukosa mulut, bentuk utamanya atropik dengan lesi eritematosa dan hiperplastik. Inflamasi ini mengakibatkan perubahan lingkungan mikroorganisme rongga mulut dan menyebabkan infeksi pada mukosa. Mikroorganisme yang sering dijumpai berkaitan dengan penggunaan gigi tiruan yaitu jamur Candida Albicans. ${ }^{6}$ Prevalensi denture stomatitis di Indonesia cukup tinggi. Menurut penelitian Sudarmawan pada tahun 2009 menyatakan bahwa $32,3 \%$ dari 30 pasien pemakai gigi tiruan terdeteksi adanya Candida Albicans. ${ }^{5}$ 


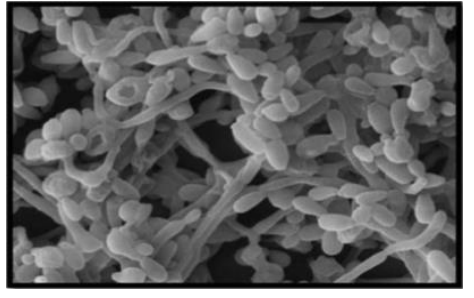

Gambar 2.3. Candida albicans. ${ }^{6}$

Candida merupakan jamur golongan khamir, yang membentuk sel ragi dan hifa semu. Di dalam tubuh manusia Candida hidup sebagai saprofit, dan dapat berubah menjadi patogen. Perubahan Candida dari saprofit menjadi pathogen menyebabkan penyakit yang disebut kandidiasis atau kandidosi. ${ }^{5}$

Pemeliharaan kebersihan gigi tiruan sangat berperan penting dalam proses perawatan gigi tiruan karena dapat membantu menjaga kekuatan, kestabilan, dan retensi gigi tiruan, serta menjaga kesehatan jaringan sekitar di dalam rongga mulut. ${ }^{7}$ Terjadinya denture stomatitis dapat dicegah antara lain dengan menjaga kebersihan gigi dan mulut termasuk kebersihan gigi tiruan yang digunakan. Salah satu cara untuk menjaga kebersihan gigi tiruan yang digunakan, lewat perendaman dalam larutan pembersih. ${ }^{7}$ Ekstrak daun pepaya memiliki daya hambat terhadap pertumbuhan Candida albicans. Dari beberapa kandungan kimia daun pepaya. Beberapa senyawa kimia dari daun pepaya yang memiliki aktivitas sebagai antifungi, yaitu alkaloid, saponin dan flavonoid. ${ }^{8}$

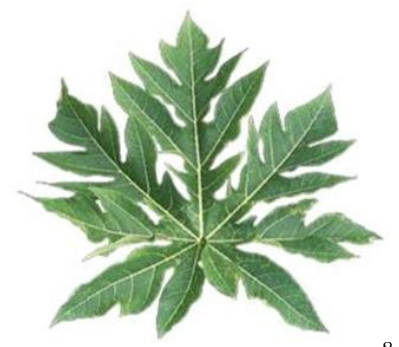

Gambar 2.6. Daun Pepaya. ${ }^{8}$

Daun pepaya (Carica papaya) merupakan salah satu tanaman yang daunnya mengandung flavonoid yang bersifat antifungi. Penelitian yang dilakukan Hidayah menyatakan bahwa ekstrak daun papaya (Carica papaya) memiliki efektivitas sebagai antifungi terhadap pertumbuhan Candida albicans. ${ }^{6}$ Daun pepaya juga mengandung senyawa-senyawa kimia yang bersifat antiseptik, antiinflamasi, antifungal, dan antibakteri. Senyawa kimia dari daun papaya yang memiliki aktivitas sebagai antifungi, yaitu alkaloid, saponin dan flavonoid. ${ }^{8}$ Berdasarkan latar belakang ini, maka penulis tertarik untuk mengadakan penelitian tentang efektivitas ekstrak daun papaya dalam menurunkan jumlah koloni Candida albicans pada plat resin akrilik dan nilon termoplastik.

\section{BAHAN DAN METODE}

Rancangan penelitian yang digunakan dalam penelitian ini adalah penelitian eksperimental dengan desain penelitian yang digunakan dalam penelitian ini adalah pretest-posttest with control group design. Resin akrilik dan nilon termoplastik yang telah dikontaminasi masing-masing dengan Candida albicans kemudian direndam dalam masing-masing bahan pembersih gigi tiruan yang diuji. 32 sampel lempeng resin akrilik dan lempeng nilon termoplastik yang digunakan adalah lempeng yang berbentuk persegi dengan ukuran 10x10x1 $\mathrm{mm}$ tanpa dipoles, dibagi menjadi masing-masing 4 kelompok (Ekstrak pepaya 10\%, 40\%, Fittydent dan Aquadest). Resin akrilik dan nilon termoplastik yang telah dikontaminasi masing-masing dengan Candida albicans kemudian direndam dalam masing-masing bahan pembersih gigi tiruan yang diuji selama 15 menit. Penelitian ini menggunakan metode TPC (Total Plate Count) untuk melakukan perhitungan jumlah Candida albicans yang masih melekat pada lempeng resin akrlik polimerisasi panas dan nilon termoplastik.

\section{HASIL DAN DISKUSI}

Berdasarkan hasil penelitian yang telah dilakukan mengenai perbedaan jumlah koloni jamur Candida albicans pada resin akrilik polimerisasi panas dan niulon termoplastik yang ditunjukkan dengan dengan rincian data sebagai berikut :

Tabel 5.1 Perbedaan nilai pengamatan jumlah koloni jamur Candida albicans sebelum dan setelah direndam dalam larutan ekstrak daun pepaya (Carica Papaya) pada plat resin akrilik polimerisasi panas $(\mathrm{CFU} / \mathrm{ml})$

\begin{tabular}{ccccccccc}
\hline & \multicolumn{1}{c}{ Pre test } & \multicolumn{7}{c}{ Post test } \\
\cline { 2 - 9 } Kelompok & Aq & F & $10 \%$ & $40 \%$ & Aq & F & $10 \%$ & $40 \%$ \\
\hline 1 & 87 & 81 & 83 & 80 & 85 & 0 & 25 & 0 \\
\hline 2 & 79 & 82 & 77 & 85 & 82 & 0 & 27 & 0 \\
\hline 3 & 84 & 83 & 78 & 81 & 80 & 0 & 25 & 0 \\
\hline 4 & 86 & 84 & 83 & 80 & 86 & 0 & 30 & 0 \\
\hline
\end{tabular}

Tabel 5.2 Perbedaan nilai pengamatan jumlah koloni jamur Candida albicans sebelum dan setelah perendaman larutan ekstrak daun pepaya (Carica papaya) pada plat nilon termoplastik (CFU/ml)

\begin{tabular}{ccccccccc}
\hline \multicolumn{3}{c}{ Pre test } & \multicolumn{8}{c}{ Post test } \\
\hline Kelompok Aq & F & $10 \%$ & $40 \%$ & Aq & F & $10 \%$ & $40 \%$ \\
\hline 1 & 78 & 85 & 79 & 83 & 76 & 0 & 9 & 0 \\
\hline 2 & 79 & 81 & 83 & 84 & 81 & 0 & 9 & 0 \\
\hline 3 & 83 & 80 & 81 & 79 & 84 & 0 & 10 & 0 \\
\hline 4 & 81 & 83 & 77 & 76 & 82 & 0 & 11 & 0 \\
\hline
\end{tabular}


Uji Paired T-Test Pada Plat Resin Akrilik Polimerisasi Panas

Uji ini dilakukan untuk mengetahui perbedaan sebelum dan sesudah perendaman sampel pada lautan aquades, fiftydent ${ }^{\circledR}$, ekstrak daun pepaya $10 \%$, ekstrak daun pepaya $40 \%$. Hasil yang di dapat dari uji ini menunjukkan adanya perbedaan antara sebelum dan sesudah perendaman pada fiftydent ${ }^{\circledR}$ sebesar 0,00 , larutan ekstrak daun pepaya $10 \%$ sebesar $0,000(\mathrm{p}<0,05)$ dan larutan ekstrak daun pepaya $40 \%$ sebesar $0,00(\mathrm{P}<0,05)$. Hal yang berbeda terjadi pada perendaman kelompok kontrol negatif (aquades) antara sebelum dan sesudah perendaman dengan nilai signifikansi $\mathrm{P}=0,650(\mathrm{p}>0,05)$ yang berarti tidak terjadi perubahan antara sebelum dan sesudah perendaman pada kelompok kontrol negatif.

Tabel 5.3 Uji paired T-Test pada plat resin akrilik (CFU/ml)

\begin{tabular}{rrrrc}
\hline kelompok & rerata & df & Sig. & Keterangan \\
\hline Aq pre-post &, 75000 & 3 &, 650 & Tidak Berbeda \\
F pre-post & 82,50000 & 3 &, 000 & $\begin{array}{c}\text { Berbeda } \\
\text { Signifikan }\end{array}$ \\
$10 \%$ pre-post & 53,50000 & 3 &, 000 & $\begin{array}{c}\text { Berbeda } \\
\text { Signifikan }\end{array}$ \\
$40 \%$ pre-post & 81,5000 & 3 &, 000 & $\begin{array}{c}\text { Berbeda } \\
\text { Signifikan }\end{array}$ \\
\hline
\end{tabular}

Uji paired T-test dilakukan untuk mengetahui perbedaan sebelum dan sesudah perendaman sampel pada lautan aquades, fiftydent ${ }^{\circledR}$, ekstrak daun pepaya $10 \%$, ekstrak daun pepapya $40 \%$. Hasil yang di dapat dari uji ini menunjukkan adanya perbedaan antara sebelum dan sesudah perendaman pada fiftydent sebesar 0,00 , larutan ekstrak daun pepaya $10 \%$ sebesar $0,000(\mathrm{p}<0,05)$ dan larutan daun pepaya $40 \%$ sebesar $0,00(\mathrm{P}<0,05)$. Hal yang berbeda terjadi pada perendaman kelompok kontrol negatif (aquades) antara sebelum dan sesudah perendaman dengan nilai signifikansi $\mathrm{P}=0,604(\mathrm{p}>0,05)$ yang berarti tidak terjadi perubahan antara sebelum dan sesudah perendaman pada kelompok kontrol negatif.

Tabel 5.4 Uji paired t-test pada nilon termoplastik (CFU/ml)

\begin{tabular}{ccccc}
\hline Kelompok & Rerata & df & Sig. & Keterangan \\
\hline Aq pre-post & -.5000 & 3 &, 604 & Tidak Berbeda \\
F pre-post & 82,250 & 3 &, 000 & Berbeda \\
10\% pre-post & 70,250 & 3 &, 000 & Berbeda \\
& & & & Berbeda \\
\hline
\end{tabular}

Pemakaian gigi tiruan yang kurang baik akan menyebabkan iritasi pada mukosa mulut. Penurunan volume saliva dapat mengakibatkan perubahan pada mukosa mulut dan merupakan predisposisi invasi jamur candida. ${ }^{5}$ Kebersihan gigi tiruan yang kurang adekuat dapat meningkatkan akumulasi plak pada permukaan tersebut. Candida albicans merupakan mikroorganisme pathogen yang mampu menghasilkan enzim hidrolitik yang bersifat toksik sehingga dapat menyebabkan terjadinya denture stomatitis. ${ }^{6}$

Bahan basis gigi tiruan akrilik, mempunyai sifat porus yang merupakan tempat ideal bagi sisa makanan untuk melekat sehingga mikroorganisme rongga mulut dapat tumbuh dan berkembang biak pada daerah tersebut. ${ }^{5}$ Pada pemakaian gigi tiruan resin akrilik, mukosa akan tertutup sehingga menghalangi pembersihan permukaan mukosa maupun permukaan gigi tiruan oleh lidah dan saliva sehingga terjadi akumulasi plak, yang dapat menyebabkan inflamasi pada mukosa palatal dan dapat menyebabkan terjadinya denture stomatitis. ${ }^{4}$

Nilon termoplastik bersifat biokompatibel, stabil dan tahan terhadap pemuaian serta beban yang tinggi. Penggunaan bahan basis gigi tiruan tersebut memiliki kekurangan yaitu pembentukan permukaan yang kasar setelah jangka waktu yang pendek. Permukaan bahan basis yang kasar tersebut dapat dapat menjadi tempat penumpukan plak gigi tiruan. ${ }^{1}$

Tabel 5.5 Uji one way anova pada plat resin akrilik polimerisasi panas $(\mathrm{CFU} / \mathrm{ml})$

\begin{tabular}{clrrc}
\hline Kelompok & & Rerata & Sig. & Keterangan \\
\hline Aq & F & $-81,75000$ &, 000 & Berbeda \\
& $10 \%$ & $-52,75000$ &, 000 & Berbeda \\
& $40 \%$ & $-80,75000$ &, 000 & Berbeda \\
\hline F & Aq & 81,75000 &, 000 & Berbeda \\
& $10 \%$ & 29,00000 &, 000 & Berbeda \\
& $40 \%$ & 1,00000 &, 598 & Tidak Berbeda \\
\hline $10 \%$ & Aq & 52,75000 &, 000 & Berbeda \\
& F & $-29,00000$ &, 000 & Berbeda \\
& $40 \%$ & $-28,00000$ &, 000 & Berbeda \\
\hline $40 \%$ & Aq & 80,75000 &, 000 & Berbeda \\
& F & $-1,00000$ &, 598 & Tidak Berbeda \\
& $10 \%$ & 28,00000 &, 000 & Berbeda \\
\hline
\end{tabular}

Tabel 5.6 Uji oneway anova pada plat nilon termoplastik (CFU/ml)

\begin{tabular}{ccccc}
\hline Kelompok & & Rerata & \multicolumn{1}{l}{ Sig. } & Keterangan \\
\hline Aq & $\mathrm{F}$ & $-82,75000$ &, 000 & Berbeda \\
& $10 \%$ & $-70,75000$ &, 000 & Berbeda \\
& $40 \%$ & $-81,00000$ &, 000 & Berbeda \\
\hline $\mathrm{F}$ & $\mathrm{Aq}$ & 82,75000 &, 000 & Berbeda \\
& $10 \%$ & 12,00000 &, 000 & Berbeda \\
& $40 \%$ & 1,75000 &, 402 & Tidak Berbeda \\
\hline $10 \%$ & $\mathrm{Aq}$ & 70,75000 &, 000 & Berbeda \\
& $\mathrm{F}$ & $-12,00000$ &, 000 & Berbeda \\
& $40 \%$ & $-10,25000$ &, 000 & Berbeda \\
\hline $40 \%$ & $\mathrm{Aq}$ & 81,00000 &, 000 & Berbeda \\
& $\mathrm{F}$ & $-1,750000$ &, 402 & Tidak Berbeda \\
& $40 \%$ & 10,25000 &, 000 & Berbeda \\
\hline
\end{tabular}


Hasil uji One way annova pada tabel 5.5 dan 5.6 menunjukkan bahwa terdapat perbedaan yang bermakna dari penurunan jumlah koloni Candida albicans pada plat resin akrilik polimerisasi panas dan nilon termoplastik pada perendaman ekstrak daun pepaya $10 \%$, aquadest steril dan fiftydent, sedangkan untuk konsentrasi daun pepaya $40 \%$ tidak terdapat perbedaan penurunan jumlah koloni pada kedua plat, karena kandungan senyawa aktif yang terdapat pada daun pepaya lebih banyak sehingga dapat menyebabkan kematian seluruh sel Candida albicans. Pada konsentrasi $10 \%$ kandungan senyawa dari ekstrak daun pepaya telah dapat menurunkan jumlah koloni Candida albicans pada kedua plat. Hal ini disebabkan, seiring meningkatnya konsentrasi ekstrak maka meningkat pula kandungan antibakterinya. Hasil penelitian ini sesuai dengan penelitian yang dilakukan Wahyuningtyas (2008) tentang pengaruh ekstrak Graptophyllum pictum dalam menghambat pertumbuhan Candida albicans pada plat gigi tiruan resin akrilik dengan konsentrasi 5\%, 10\%, 20\% dan 40\%. ${ }^{9}$ Perendaman dalam larutan ekstrak daun pepaya dengan konsentrasi $10 \%$ pada plat resin akrilik polimerisasi panas dan nilon termoplastik tidak seefektif menggunakan fittydent ${ }^{\circledR}$.

Penurunan jumlah koloni Candida albicans dapat dilihat pada perendaman plat menggunakan ekstrak daun papaya $10 \%$, dimana persentase penurunan paling besar pada plat nilon termoplastik $(87,8 \%)$ dibandingkan dengan plat resin akrilik $(66,67 \%)$.

Tabel 5.7 Perbandingan Jumlah Koloni Candida albicans pada plat nilon termoplastik

\begin{tabular}{|c|c|c|c|c|c|c|}
\hline & Kelompok & df & Rerata & Sig. & Ket & 5. \\
\hline \multirow[t]{2}{*}{ Aquadest } & Resin Akrilik & 6 &, 7500 & ,496 & Tidak & \\
\hline & Nilon Termoplastik & 4,813 &,- 5000 &, 503 & Berbeda & \\
\hline \multirow[t]{2}{*}{$\mathrm{F}$} & Resin Akrilik & 6 & 82,5000 & ,852 & Tidak & \\
\hline & Nilon Termoplastik & 4,824 & 82,2500 &, 853 & Berdeda & 6. \\
\hline \multirow{2}{*}{$\begin{array}{l}\text { Ekstrak } \\
10 \%\end{array}$} & Resin Akrilik & 6 & 53,5000 & ,000 & \multirow{2}{*}{\multicolumn{2}{|c|}{ Berbeda signifik }} \\
\hline & Nilon Termoplastik & 6,000 & 70,2500 & , 000 & & \\
\hline \multirow{2}{*}{$\begin{array}{l}\text { Ekstrak } \\
40 \%\end{array}$} & Resin Akrilik & 6 & 80,5000 & ,665 & \multirow{2}{*}{$\begin{array}{l}\text { Tidak } \\
\text { Berbeda }\end{array}$} & 7. \\
\hline & Nilon Termoplastik & 5,123 & 81,5000 & ) ,668 & & \\
\hline
\end{tabular}

Alkaloid dalam daun pepaya berperan sebagai antifungi dimana secara mekanisme kerja dapat menghambat biosistensis asam nukleat. ${ }^{8}$ Saponin berkontribusi sebagai anti fungi dengan mekanisme kerja menurunkan tegangan permukaan membran sterol dari dinding sel Candida albicans, sehingga permeabilitasnya meningkat. Permeabilitas yang meningkat mengakibatkan cairan intraseluler yang lebih pekat tertarik keluar sel yang mengakibatkan Candida albicans mengalami kematian. ${ }^{7}$
Flavonoid merupakan salah satu kelompok senyawa metabolit sekunder yang paling banyak ditemukan di dalam jaringan tanaman yang berfungsi sebagai antioksidan dan antijamur. ${ }^{9}$ Flavonoid bekerja dengan cara denaturasi protein sehingga meningkatkan permeabilitas membran sel. Denaturasi protein menyebabkan gangguan dalam pembentukan sel sehingga merubah komposisi komponen protein fenol. Fenol yang terdapat pada flavonoid dapat mengakibatkan terjadinya denaturasi protein sel dan mengerutkan dinding sel sehingga menyebabkan lisisnya dinding sel jamur. ${ }^{8}$

\section{SIMPULAN}

Ektrak daun papaya efektif dalam menurunkan jumlah koloni Candida albicans pada plat resik akrilik dan nilon termoplastik.

\section{DAFTAR PUSTAKA}

1. Sumartati, Y., Saleh, S., Dipoyono, H,M., 2013, 'Pengaruh konsentrasi alkohol dan lama penggunaan obat kumur terhadap modulus elastistas thermoplastic nylon sebagai bahan basis gigi tiruan', Jurnal kedokteran gigi, 2(4), 304- 12.

2. McCabe, J.F \& Walls, A.W.G., 2008, 'Applied Dental Materials', 9th Ed. Blackwell Publishing, Singapore, hal. 110-123.

3. Car, A.B., 2010, 'McCracken's removable partial prothodontics', 11th Ed. Elsevier Mosby., Canada. hal 131-32.

4. Khindria, S.K., Mittal, S., Sukhija, U. 2017, 'Evolution of Denture base Materials',The journal of indian prosthodontic society, (9).

5. Pambudi, R.R., Sulistyorini, R., Mayasari, L.O., 2017, 'Perbedaan perendaman plat resin arilik pada tablet pembersih gigi tiruan effervescent dan air rebusan daun sirih terhadap penurunan jumlah koloni jamur Candida albicans,'.

6. Suni, N.A., Wowor, V.N.S., Leman, M.A., 2017, 'Uji daya hambat rebusan daun pepaya (carica papaya) terhadap pertumbuhan Candida albicans pada plat resin akrilik polimerisasi panas', Jurnal e-GIGI, 5(1).

7. Bagaray, D.A., Mariati, N.W., Leman, M.A., 2014, 'Perilaku memelihara kebersihan gigi tiruan lepasan berbasis akrilik pada masyarakat desa treman kecamatan kauditan', Jurnal e-gigi 2 (2).

8. Rosari, I.R., Zulfian., Sjahriani, T., 2014, 'Pengaruh ekstrak daun pepaya (Carica papaya L.) terhadap pertumbuhan Candida albicans', Jurnal ilmu kedokteran dan kesehatan, 1(2).

9. Wahyuningtyas, E., 2008, 'Pengaruh ekstrak graptophyllum pictum terhadap pertumbuhan Candida albicans pada plat gigi tiruan resin akrilik', Indonesian Journal of Dentistry 15 (3), 187-91. 